Александар Прњат

Алфа БК Универзитет

Факултет за стране језике

aleksandar.prnjat@gmail.com
299.5

https://doi.org/10.18485/melissa.2017.16.2.ch13

\title{
ЕТИКА АУТЕНТИЧНОСТИ И СЕКУЛАРИЗАЦИЈА
}

Чарлс Тејлор (Charles Taylor) је концепцију етике аутентичности развијао у многим својим радовима и она је увек интимно била повезана са масовним губитком религијске вере на Западу у модерно доба. У књизи Секуларно доба Тејлор је повезује пре свега са стањем вере после другог светског рата. Људи у западним друштвима, примећује он, осећају да је дошло до извесног опадања значаја породице, суседства и државне заједнице. Многи међу њима ово осећају као губитак. Тејлор без увијања указује да је ово повезано са порастом етике аутентичности која је са своје стране блиска извесном етичком релативизму. Тај релативизам се састоји у схватању да не треба критиковати друге због вредности које следе у својим животима. У овом раду биће изложено Тејлорово истраживање односа између етоса аутентичности и секуларизације западних друштава.

Кључне речи: етика аутентичности, секуларизација, култура, западна друштва, модерност

1.

Концепција етике аутентичности коју је развио Чарлс Тејлор (Charles Taylor) интимно је повезана са модерном. Њу Тејлор није развио као сопствено етичко учење, нити је уопште реч о некој филозофској доктрини, нормативној или метаетичкој. Реч је пре свега о једној дескриптивној, односно дијагностичкој концепцији, делимично у оном смислу у којем је Макс Вебер (Max Veber) говорио о протестантској етици (Veber 2017). Секуларизам и лаицизам обично означавају потискивање религије из јавног домена као и масовни губитак религијске вере. Додуше, израз лаицизам би се могао употребљавати и на један другачији начин, наиме: да означи улогу лаика у црквеним пословима (Прњат 2013а). У сваком случају, одно- 
сно у оба случаја, изрази секуларност и секуларизација задржавају истоветно значење. То је значење које користи и Тејлор, а у овом раду се излаже његово истраживање односа између етике аутентичности и секуларизације модерних западних друштава, које врхуни у књизи Секуларно доба (Taylor 2007) ${ }^{1}$ и која је у српском преводу објављена четири године касније (Tejlor 2011). На њеном почетку Тејлор каже да су термини „секуларно“ и „секуларност“ јасни све док не почнемо да размишљамо о њима, али када то учинимо наилазимо на најразличитије тешкоће (24). Ова његова опаска подсећа на једно запажање о времену које се приписује Светом Августину (Aurelius Augustinus), а по којем он зна шта је време - све док не мора да одговори на то питање

2.

Када говори о секуларном добу Тејлору је јасно да епохално ограничење није довољно, односно, да секуларност није само оно што одликује модерно друштво од предмодерних², већ да је потребно увести и једно просторно, односно, географско ограничење. Утолико он онда о секуларности говори у друштвима Запада, или нешто уже северозапада или користећи политичку одредницу, о друштвима северноатлантског света (11). У овим друштвима питање о религији, примећује он, обично се одређује преко веровања (14). Реч је, дакако о хришћанским друштвима. Потискивање хришћанске вере од стране науке у овим друштвима је једно од стандардних објашњења секуларзизације, али Тејлор није задовољан овим објашњењем (исто). Тејлорова скепса према оваквом објашњењу почива, по његовом саморазумевању, на две различите али међусобно пове-

1 На десетогодишњицу од првог издања Тејлорове књиге објављен је зборник радова који јој је посвећен. Види: Hansen 2017.

2 Наступање секуларног доба Тејлор понекад поистовећује, грубо говорећи са модерним добом, односно позива се на уобичајено схватање по којем је секуларност производ модерног доба (Тејлор 2011: 30), док у другим случајевима о секуларном добу говори као о ономе које настаје после Другог светског рата. Понекад међутим, једноставно избегне постављање оштрих граница и позове се на разлику између односа према вери у 1500. и 2000. години $(35,38)$. 
зане интуиције (исто). По првој развој науке није убедљив разлог за одбацивање религије. Тејлор у виду има теорију еволуције и Дарвинова (Charles Darwin) открића, ${ }^{3}$ али и неуропсихолошка објашњења свести (исто) 4 . Из овог произилази и друга Тејлорова интуиција, која се делом наслања на прву. Реч је о томе да, по њему ова открића не могу довољно објаснити губитак вере (исто). Уместо разматрања ривалских позиција веровања и неверовања, Тејлор би желео да размотри различите врсте искуства које произлазе из ових животних позиција, као и то на који начин она утичу на разумевање живота (исто).

3.

Као што жели да избегне супротстављене позиције веровања и неверовања, исто тако избегава позиције бранитеља и критичара етике аутентичности (Tejlor 2002: 89). Као њену полазну тачку, могли би, по Тејлору, да узмемо теорију моралног чула (29). Сврха ове теорије, по Тејлору, била је побијање концепције по којој је морално знање ствар калкулације последица (исто). Реч је о последицама у виду божанске казне или награде а теорија моралног чула је насупрот овом прорачунавању, и као његову допуну, уводила интуитивни осећај за исправно и погрешно (исто). Теорију моралног чула, заступао је Франсис Хачесон (Frensis Hacheson) и њу Тејлор представља на следећи начин. Када делујемо морално нас поред егоизма покрећу и неки други мотиви који су племенити и који превазилазе самољубље (Tejlor 2008: 393 - 394). Зато се и дивимо непријатељу који је одан својој идеји у чему видимо нешто витешко, а осећамо презир према издајнику непријатељске стране иако је његова издаја за нас корисна (393). Када Хачесон критикује спољашњу теорију морала, он не избацује увид ове теорије о важности личног интереса (398). По Тејлору теоретичари спољашњег морала су погрешно порицали главне мотивације моралног делања, а порицањем добронамерности у нашој природи пориче се оно што нас уопште покреће у моралном животу (399). Уочавање

3 Другачије: Dennett 1995.

4 Упор. нпр. Dennett 1991. 
ових извора доброте људских бића је, по Хачесону, важна морална мотивација. Оно нас чини бољим и зато је важно уочавати добро у другим људима али и у Богу (400). Тејлор указује на Хачесоново схватање по којем је осећај љубави и захвалности према Богу морални покретач за достизање врхунца доброте (405).

\section{1.}

Концепција етике аутентичности развија се инсистирањем на унутрашњем гласу моралности (Тејлор 2002: 29). Тејлор указује да је унутрашњи глас изворно важан, јер нас упућује на то шта треба да учинимо, он је дакле значајан као средство док је циљ исправно делање (исто). За етику аутентичности важно је оно што Тејлор назива „померање моралног акцента ове идеје“ (Op. cit. 29). Реч је о томе да сам контакт са моралним осећањем, добија независан значај и да је он нешто што морамо да остваримо да би постали „истинска и довршена људска бића“ (Оp. cit. 30). За разлику од овога у старијим теоријама морала као суштинска ствар која је потребна да би смо постали оваква људска бића јесте контакт са једним спољним извором као што је идеја добра у платонизму или Бог у хришћанству (исто) ${ }^{5}$.

\section{2.}

Идеја контакта са самим собом је настала еманципацијом од идеје контакта са светом идеја или са Богом. Утолико су њене прве верзије биле теистичке. Као најважнијег филозофског аутора који је допринео ширењу ове концепције аутентичности, Тејлор наводи Русоа, пре свега због тога што је он „артикулисао нешто што се у култури већ догађало“ (30). Говорећи о Русоу (Jean Jacques Rousseau), Тејлор каже да са њим:

...слобода постаје основ за ново дефинисање врлине, а поредак узајамне користи постаје неодвојив од поретка који осигурава врлину самозависности. Али и Русо и његови следбеници централни нагласак стављају на обезбеђивање слободе, једнакости и потреба свакодневног живота (Tejlor 2011: 176).

5 Вернер Бајервалтес (Werner Beierwaltes) је детаљно истражио утицај платонизма у на хришћанску теологију. Упор. Бајервалтес 2009. 
Русо је артикулисао идеју да је човек слободан тиме што сам одлучује шта је за њега одређујуће (Tejlor 2002: 31). Ово Тејлор назива самоодређујућом слободом (исто). Идеал самоодређујуће слободе Тејлор резимира на следећи начин: „слободни смо онда када можемо изменити услове сопствене егзистенције, када можемо контролисати ствари које контролишу нас" (96). Ова идеја имала је велики утицај у политичком животу. Политички облик код Русоа она има преко концепције државе базиране на друштвеном уговору, односно заснованој на општој вољи (Русо 1993: 35 - 37; 101 - 103). Тејлор упозорава да је она један од интелектуалних извора модерног тоталитаризма (Tejlor 2002: 31). Ту идеју је Кант (Imanuel Kant) у својој филозофији морала прочитао као идеју аутономије, да би се она касније вратила у област политичког преко Хегела (Georg Wilhelm Friedrich Hegel) и Маркса (Carl Marx) (31). Могли бисмо додати да је идеја слободе као самоодређења имала велики утицај и у марксизму а у српској филозофији њу је у најразвијенијем облику заступао Михаило Марковић (Михаило Марковић) (Марковић 1997).

\section{3.}

Етика аутентичности свој пуни значај, по Тејлору задобија тек благодарећи догађајима после Русоа а који је повезан са Хердером (Herder). Реч је о Хердеровом схватању да сваки човек има своју властиту меру (32). Ово Тејлор тумачи као схватање по којем „свако од нас поседује оригиналан начин да буде људско биће“ (32). То, наставља Тејлор, имплицира нову интерпретацију концепције верности себи: њен недостатак водиће у озбиљан животни промашај. Промашиће се смисао сопственог живота а то значи да нико не треба да имитра туђи живот већ да живи свој сопствени. Тејлор указује да овакво придавање моралног значаја разлици између људских бића пре краја осамнаестог века није уопште постојало. Овај идеал аутентичности ствар је модерног доба и имплицира у себи вредности као што су самоиспуњење или самоостварење (33).

Из овога произлази суштински значај контакту са самим собом. Са овим контактом са собом, са сопственом унутрашњим гласом, повезано је и принцип оригиналности. Ово имплицира одбацивање спољашњих захтева, пошто образац на основу којег ћемо води- 
ти свој живот можемо пронаћи само унутар себе самих (32). Тејлор настоји да непристрасно реконструише и са великом интелектуалном искреношћу ${ }^{6}$, опише захтеве етике аутентичности не спорећи да она има и сасвим апсурдне и тривијалне изданке (33).

4.

Овакво схватање самоиспуњења, у етици аутентичности, примећује Тејлор, занемарује значај заједнице којој неко припада (45). Тиме се она редукује на један потпуно инструментални ниво. Маргинализује се не само посвећеност заједници, осећај дужности према њој већ се подстиче схватање да је свака врста заједнице и свака врста односа међу људима нешто што треба да допринесе интересима личног самоиспуњења и самоостварења. Тејлор каже: „из овакве перспективе, безусловне везе, оне које треба да трају доживотно, немају много смисла" (45). Рекло би се да Тејлор, ово говори из перспективе, или барем имајући у виду перспективу католичког схватања брака.

Тејлор дијагностификује два облика друштвене егзистенције као повезане са савременом етиком аутентичности и самоиспуњења. Први се односи на оно што он назива меки релативизам као морално начело, а реч је о томе да „нико нема право да критикује вредности другог“ (46). Реч је дакле о концепцији универзалног права из којег произлази да "свако треба да има право и могућност да буде то што јесте“ (исто). Други облик друштвене егзистенције се односи на интимну област људског живота, специфично на љубавне односе. Управо су они у овом идеалу виђени као један од основних облика самоиспуњења (47). Овим се, по Тејлору, продужава једна тенденција модерне културе која је старија од савременог доба и која идеал доброг живота не поставља више у некој вишој сфери, већ у ономе што Тејлор назива обичним животом (47) ${ }^{7}$. Реч је о животу производње, рада и љубави.

6 На Тејлорову интелектуалну искреност посебно је скренуо пажњу његов старији колега Исаија Берлин (Isaiah Berlin). Упор. Berlin 1994: 1

7 За Тејлорово истраживање афирмације обичног живота упор. Прњат 20136. 


\section{Извори и литература:}

Бајервалтес, Вернер. Платонизам у хришћанству. Нови Сад: Академска књига, 2009. Штампано.

Berlin, Isaiah. "Introduction“ in Charles Tully (ed.) Philosophy in age of pluralism: The philosophy of Charles Taylor in question. New Yor, Melbourne: Cambridge University Press, 1994. 1 - 3. Štampano.

Dennett, Daniel. Darwin's Dangerous Idea: Evolution and the Meaning of Life. New York, Toronto, London, Sydney: Simon \& Schuster Paperbacks, 1995. Štampano.

Dennett, Daniel. Consciousness Explained. New York: Little Brown and Company, 1991. Štampano.

Hansen, Collin (ed.) Our Secular Age: Ten years of reading and applying Charles Taylor. Deerfield: The Gospel Coalition. 2017. Štampano.

Марковић, Михаило. Слобода и пракса. Београд: Завод за уџбенике и наставна средства, 1997. Штампано.

Прњат, Александар. „Појмови секуларизма и лаицизма“. Култура, бр. 140 (2013а): 473 - 478. Штампано.

Прњат, Александар. „Култура модерности и афирмација обичног живота“. Вранеш Александра, Марковић Љиљана (прир.), Књижевност и мултикултуралност, (Културе у дијалогу, књ. 2). Београд: Филолошки факултет Универзитета, 20136. 147 - 155. Штампано.

Ruso, Žan-Žak. Društveni ugovor. Ruso, Žan-Žak. Društveni ugovor; O poreklu i osnovima nejednakosti među ljudima; Rasprava o naukama i umetnostima. Beograd: Filip Višnjić, 1993. 25 - 128. Štampano.

Tejlor, Čarls. Doba sekularizacije. Beograd: Albatros plus, Službeni glasnik, 2011. Štampano.

Taylor, Charles. A Secular Age. Cambridge, Massachusetts, London, England: The Belkanp Press of Harvard University Press, 2007. Štampano.

Tejlor, Čarls. Bolest modernog doba. Beograd: Beogradski krug, Čigoja štampa, 2002. Štampano.

Tejlor, Čarls. Izvori sopstva: Stvaranje modernog identiteta. Novi Sad: Akademska knjiga, 2008. Štampano.

Veber, Maks. Protestantska etika i duh kapitalizma. Beograd: Filip Višnjić, 2017. Štampano. 


\title{
Aleksandar Prnjat
}

\section{ETHICS OF AUTHENTICITY AND SECULARIZATION}

\begin{abstract}
Summary
In many of his works, Charles Taylor developed the conception of the ethics of authenticity, which has always been intimately linked with mass loss of religious faith in the West in modern age. In his Secular Age, Taylor connects the ethics of authenticity with the state of faith after the World War II. He observes that ordinary people in west societies feel that there has been certain decline of the importance of family, neighborhood and state community. Many of them consider this as a loss. Taylor straightforwardly shows its connection with the increase of the ethics of authenticity that is itself close to certain ethical relativism. This relativism consists of the idea that one should not criticize others for the values they cherish. In this paper, the author will expose Taylor's theory of secularization and the ethics of authenticity of the western societies.
\end{abstract}

Key words: ethics of authenticity, secularization, culture, western societies, modernity 